\title{
The Registration of the Mid-Paleocene Biotic Event (MPBE) in Tunisia
}

\author{
Narjess Karoui-Yaakoub, ${ }^{1,2}$ Moncef Saïd Mtimet, ${ }^{1}$ Mohamed Hédi Negra, ${ }^{2,3}$ \\ Chaima Grira, ${ }^{1,2}$ and Wafa Gusemi ${ }^{1,2}$ \\ ${ }^{1}$ Département des Sciences de la Terre, Faculté des Sciences de Bizerte, Université de Carthage, Jarzouna, 7021 Bizerte, Tunisia \\ ${ }^{2}$ Unité de Recherche: Pétrologie Sédimentaire et Cristalline, Université de Tunis El Manar, 1068 Tunis, Tunisia \\ ${ }^{3}$ Département de Géologie, Faculté des Sciences de Tunis, Université de Tunis El Manar, 1068 Tunis, Tunisia
}

Correspondence should be addressed to Narjess Karoui-Yaakoub; narjess1999@yahoo.fr

Received 16 July 2014; Accepted 8 September 2014; Published 18 September 2014

Academic Editor: Francisco Rodríguez-Tovar

Copyright (C) 2014 Narjess Karoui-Yaakoub et al. This is an open access article distributed under the Creative Commons Attribution License, which permits unrestricted use, distribution, and reproduction in any medium, provided the original work is properly cited.

\begin{abstract}
In Tunisia, the Paleocene biomarkers are identified within the El Haria Formation shales. The Selandian is absent in most of the Paleocene outcrops and the Thanetian is unconformable to different stages of the Cretaceous. In the middle of Selandian, with the beginning of the Globanomalina pseudomenardii (P4) zone, we note that the assemblage of planktonic foraminifera becomes very poorly preserved and much less abundant than at the base. It is represented by rare species and there has been a start of the microfauna dissolution tests and an enrichment in iron oxides, silica, and gypsum crystals. The dissolution process is increasing more and more and a drop in the content of carbonates is clearly recorded at the top of Selandian. However, we note that some small benthic foraminifera belonging to the genera Lenticulina and Anomalina escape the dissolution and very few planktonic foraminifera belonging to the genera Subbotina are preserved. This dramatic and abnormal dissolution extends over a considerable thickness. These features could be an expression of the mid-Paleocene biotic event (MPBE), registered for the first time in Tunisia. This intense dissolution is caused probably by the change in the solubility of carbonates, which may be related to the changes in the deep-water circulation or to the change in the productivity of the surface waters.
\end{abstract}

\section{Introduction}

The mid-Paleocene biotic event (MPBE) has been described at the beginning, offshore in some studies of deep-sea sections, at Shatsky Rise (Ocean Drilling Program, central Pacific) and Walvis Ridge (south Atlantic) (e.g., [1-5]). In 2007, this event was first recognized onshore, in the Zumaia section (western Pyrenees) (e.g., [6]). This event is characterized by the existence of a remarkable dissolution level in the carbonate sediments and it was short lived and probably related to hyperthermal events (e.g., [1-3, 7]).

The aim of this paper is to show the micropaleontologic and geochemical analysis of the middle Paleocene series in the northwest of Tunisia (Tejerouine section), the evidence of the mid-Paleocene biotic event (MPBE) similar to the one described previously. We want to demonstrate that this event is also recorded in Tunisia and, therefore, is a worldwide event. It needs intensive work to get more information and to find far more interpretations.

\section{Material and Methods}

The Paleocene series are complete, well exposed, and easily accessible, in the Tejerouine section. In the field, the sampling was done particularly in marls and was tighter at the boundaries. In the laboratory, samples of marls were dipped in the tap water and then washed through sieves. The residues thus obtained were dried in the oven to at least $50^{\circ} \mathrm{C}$ and then sorted under a binocular microscope to extract the microfauna. The qualitative and quantitative analysis of the microfauna collected has concerned the fraction above $63 \mu \mathrm{m}$. The same samples have been the subject of a geochemical analysis.

\section{Geology and Lithostratigraphy}

The Tejerouine region is part of the northwest of Tunisia, the El Kef area, in the Tunisian Atlas (Figure 1). The section is 


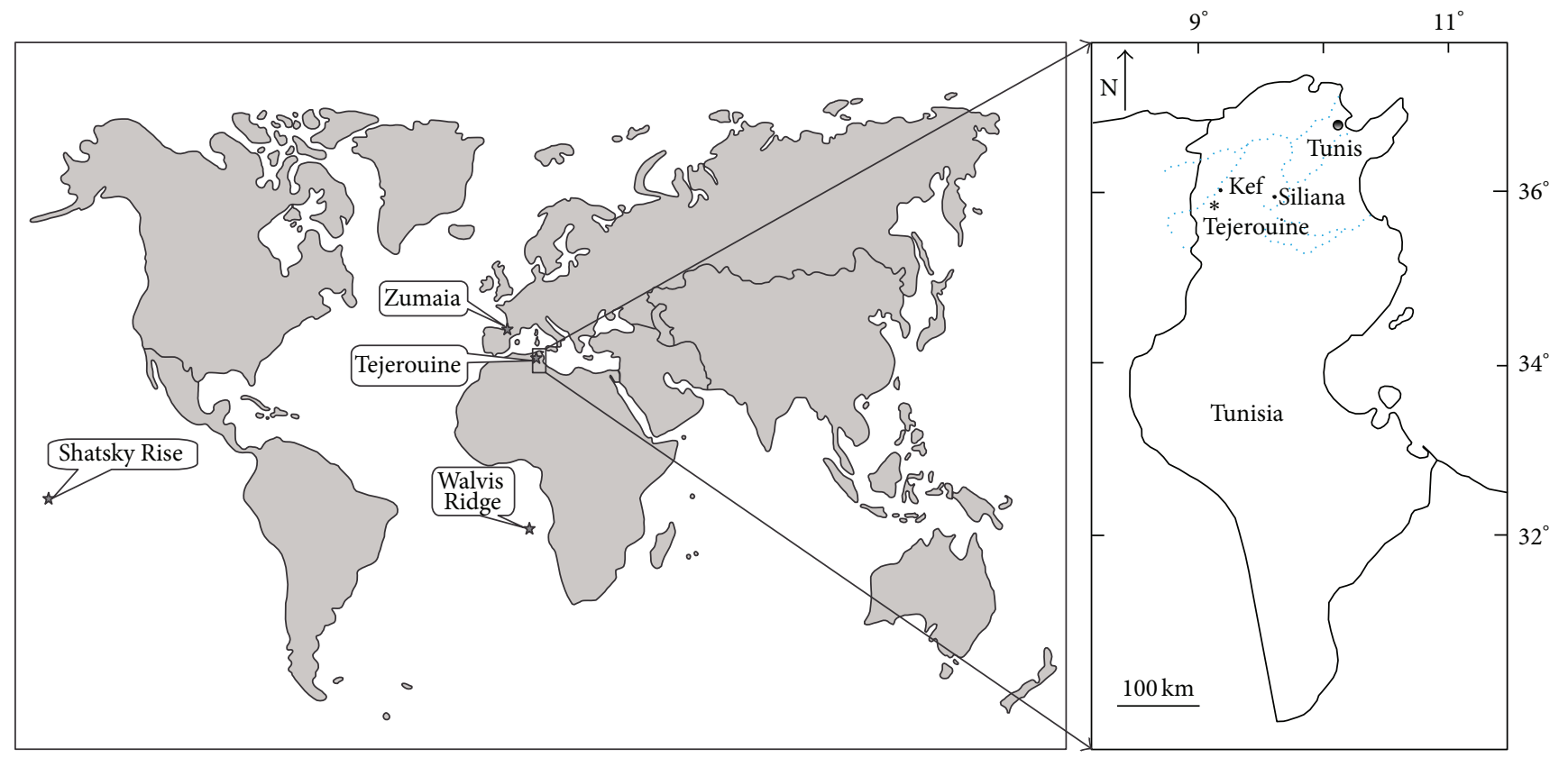

* Section

Wadi

Figure 1: Location of the Tejerouine section in Tunisia.

located on the geological map labeled, Tejerouine on the scale 1/50000, in the level of the lambert coordinate points: $\mathrm{N} 35^{\circ} 52^{\prime}$ $44.06^{\prime \prime}, \mathrm{E}^{\circ} 37^{\prime} 51.83^{\prime \prime}$.

The Paleocene was first recognized in the El Haria Formation (e.g., [8]) which overlies the upper Cretaceous Abiod Formation. When it is complete, the Paleocene is represented by Danian, Selandian, and Thanetian stages and it crops out only in some areas in western and north-central Tunisia. In terms of lithology, the Paleocene interval is represented by grey marls admitting the intercalation of decimetric slightly argillaceous limy beds.

\section{Results and Discussion}

The El Haria Formation is characterized by relatively deepwater deposits, which consist of marls and occasionally limestone. The marls, which generally show a low TOC content, are rich in planktonic foraminiferal assemblages. Planktonic foraminiferal assemblages are diverse and are composed of the genera Morozovella, Acarinina, Igorina, Globanomalina, Pseudohastegerina, and Subbotina (Figure 2). Benthic assemblages, which are characterized by Midway, mixed Midway, and Velasco-type faunas, are also diversified. The lower boundary of the middle Paleocene or the Danian/Selandian (D/S) boundary coincides with the bioturbated limy bed with variable thickness, rich in glauconitic grains and phosphates, which is recorded by a peak of $\mathrm{P} 2 \mathrm{O} 5$ in Figure 4. In micropaleontological terms, the $\mathrm{D} / \mathrm{S}$ boundary coincides with the first appearance of the species Igorina albeari (e.g., $[9,10]$ ) (Figure 2). This bioturbated limy bed could be used as a good marker of the $\mathrm{D} / \mathrm{S}$ boundary and reflects a global event well recorded on the biostratigraphic and lithological composition.

Selandian deposits are absent in most outcrops in Tunisia and Thanetian deposits are unconformably overlying Danian or Cretaceous deposits and are being clearly transgressive. When it is present, the Selandian is also located in the middle grey marl of El Haria Formation. The Selandian interval is rather rich in planktonic and benthonic foraminifera. It is remarkable that the species represented by the genera Morozovella and Subbotina are the most abundant (Figures 2 and 3 ). At the top of the Selandian, with the beginning of the Gl. pseudomenardii (P4) zone, it should be noted that the planktonic foraminifera become very poorly preserved and much less abundant than the Selandian (e.g., [11]).

They are represented by three species of the genus Acarinina, one species of Igorina, four species of Morozovella, three species of Globanomalina, four species of Subbotina, and one species of Parasubbotina. However, the extinction of Woodringina is worth mentioning. The upper part of the Selandian is represented by three species of Morozovella, three species of Globanomalina, three species of Subbotina, and two species of Acarinina, whereas both the genera of Igorina and Parasubbotina are extinct (Figure 3).

This assemblage is mostly represented by the species belonging to the group "Subbotina" having globular chambers. It becomes less abundant, much less diversified, and represented by small species. The number of the benthic foraminifera clearly exceeds that of the planktonic foraminifera. There has been a start of the microfauna's tests dissolution and enrichment in iron oxides and gypsum crystals. The $\mathrm{CaO}$ content decreases substantially and reaches the lowest 


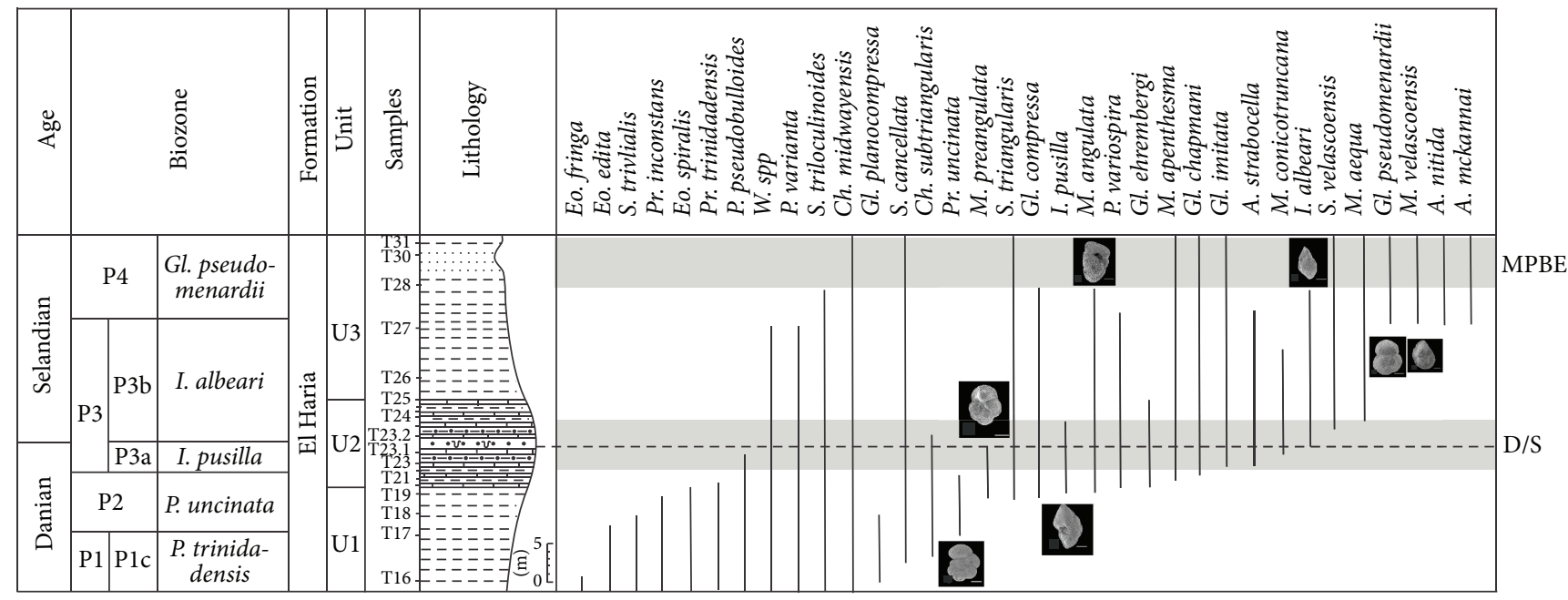
v Bioturbations
Eㅋ Marls
Glauconites
四 Limestones
Dissolution

FIGURE 2: Vertical distribution of planktonic foraminifera in the Tejerouine section.

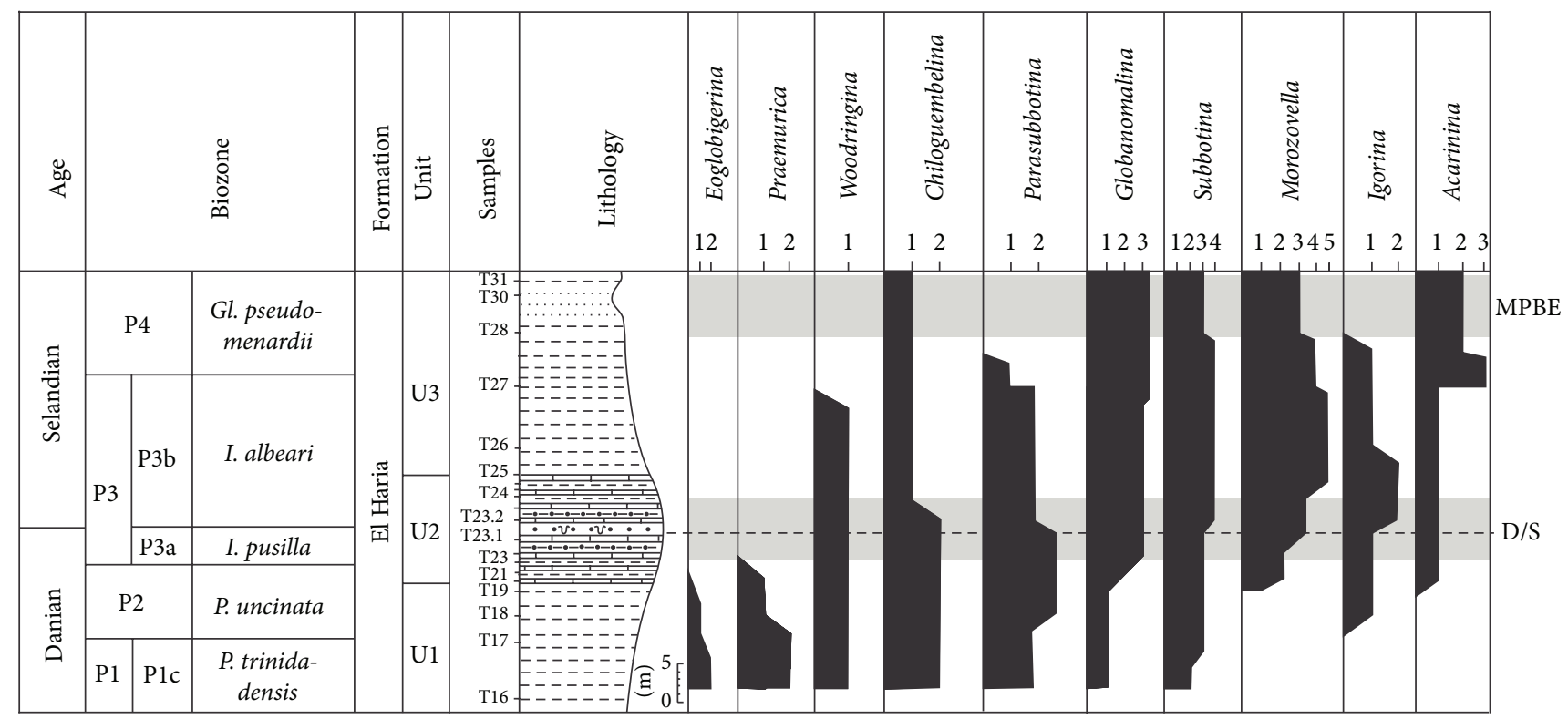

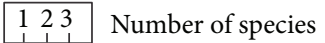

FIgURE 3: Abundance of planktonic foraminifera in the Tejerouine section.

value $(7,33 \%)$, while the content of the oxides of $\mathrm{Fe}, \mathrm{Al}$, $\mathrm{Mg}$, and $\mathrm{Na}$ has the highest ratio. $\mathrm{SiO}_{2}$ is the most abundant element and reaches the maximum value $(49,44 \%)$ in the sample T30, where the maximum dissolution of carbonates was recorded (Figure 4). The phenomenon of dissolution process of the tests is increasing more and more upwards. Many tests, which are dissolved and partly fragmented, are associated with gypsum crystals and oxides. A similar pulse of intense carbonate dissolution and richness in clays is noted at the same moment as the dissolution event, which is registered by the planktonic foraminiferal assemblages in the Zumaia section, western Pyrenees (e.g., $[1,2,5])$.

However, some small benthic foraminifera belonging to the genera Lenticulina and Anomalina escape the dissolution and very few planktonic foraminifera belonging to the genus Subbotina persist.

More than ten meters from the base of P4, there has been an increase in the ratio of gypsum crystals and iron oxides, sometimes with the presence of glauconitic grains and phosphates (Figure 4). The dissolution affects most of the 


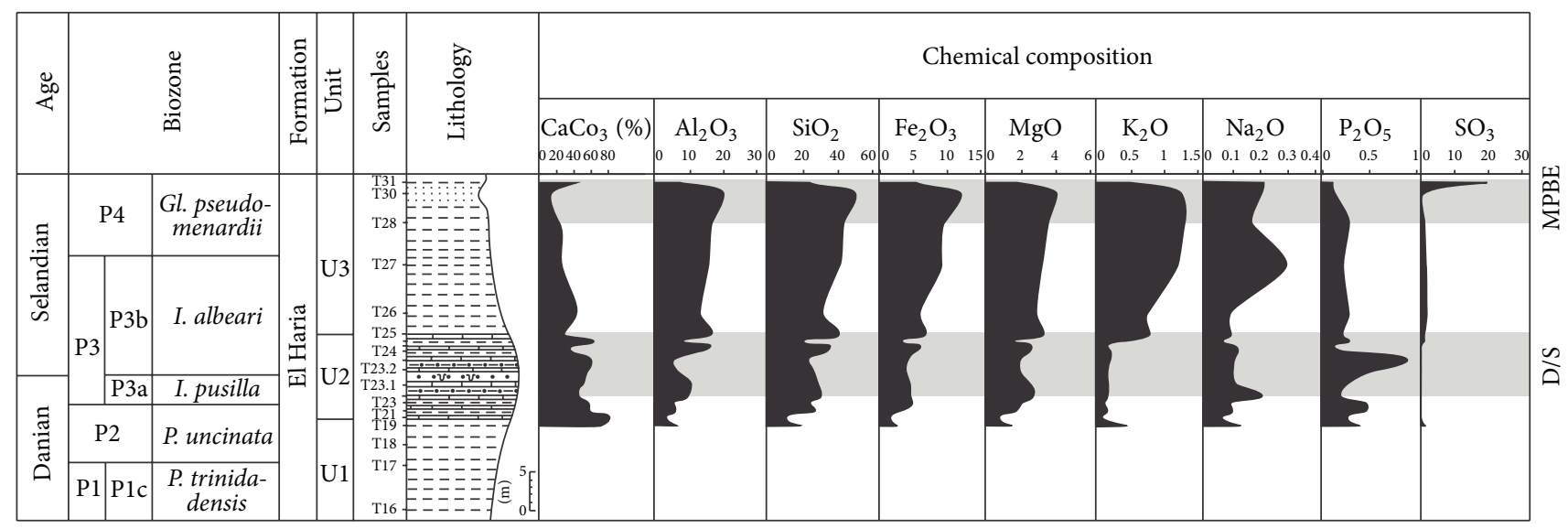

FIgURE 4: Vertical distribution of geochemical elements in the Tejerouine section.

microfauna's tests. At the top of the section, dissolution of the tests is still underway. The presence of some small specimens of benthic foraminifera, with spiral and trochospiral coil, seems to escape the dissolution. There is also richness in gypsum crystals and oxides of $\mathrm{Al}, \mathrm{Fe}$, and $\mathrm{Mg}$.

This dramatic and abnormal dissolution of the tests extends some ten meters in the Tejerouine section. However, it should be noted that within this interval there is sometimes a brief phase of development of the association; indeed, the microfauna seems more abundant and diversified and enriched by individuals belonging to diverse genera of benthic foraminifera such as Frondicularia, Palmula, Lenticulina, Nodosaria, and Lagena, as well as some planktonic foraminifera such as Morozovella spp., Subbotina spp., and also shark teeth, suggesting that favorable conditions come back again and announce the end of the crisis period or probably they represent the type of opportunistic taxa. This interval of the growth of the microfauna was located on the field and corresponds to enrichment in carbonates, which is recognized by the alternations of thin beds of clayey limestone and light grey marls. This shows that, during this phase of biological crisis, there was probably a return to the favorable conditions but it was short lived. This intense dissolution is caused probably by the change in the solubility of carbonates, which may be related to the changes in the deep-water circulation or to the change in the productivity of the surface waters (e.g., $[4,6,12,13])$. Above all, the dissolution continues until the top of the Selandian series and probably the base of Thanetian, but, with a lower intensity, it diminishes more and more.

\section{Conclusions}

The quantitative and qualitative analysis of foraminifera at the top the Selandian reveals important changes in faunal composition. The major calcareous planktonic and benthonic foraminiferal changes indicated a disturbed environment due to the warming of the ocean.

The mid-Paleocene biotic event (MPBE) is characterized by the existence of an abrupt environmental disruption that occurred in the photic zone and at the seafloor during the upper middle Paleocene, documented by a decrease in the percentage of calcite and an increase in the percentage of silicate minerals and the oxides. The expression of this MPBE mainly corresponds to the solution features affecting most of the microfauna's shells, which was short lived. The major calcareous plankton assemblage changes indicate the oligotrophic conditions and disturbed environment due to the warming of the ocean. Benthic foraminifer assemblages were also significantly affected; diversity of the assemblage shows net decline and the low food and opportunistic taxa increase in abundance. Dissolution processes could be in relation to a change of the original composition of a large part of the water column. This dissolution was probably caused by the change in the solubility of carbonates or related to the changes in the deep-water circulation. In conclusion, the MPBE is recorded in the entire world, in the oceans, such as Shatsky Rise (central Pacific Ocean), in Walvis Ridge (south Atlantic), and in the land-based localities like Zumaia (western Pyrenees) and Tejerouine sections (Tunisia) in which the MPBE is recognized by its expanded character and excellent paleontological record.

\section{Conflict of Interests}

The authors declare that there is no conflict of interests regarding the publication of this paper.

\section{Acknowledgments}

The authors thank Mr. Houcine Tiss, engineer at Bizerte cement plant, for his availability in providing the geochemical analyses and Professor Ijed Moussa, specialist in English and teacher at the Institut des Hautes Etudes Commerciales de Carthage, for her kind availability in revising the English of this paper. The authors thank anonymous reviewers delegated by the Paleontology Journal and the Editor Professor Francisco Rodríguez-Tovar for their suggestions allowing them to improve our paper. 


\section{References}

[1] T. J. Bralower, I. Premoli-Silva, and M. J. Malone, "New evidence for abrupt climate change in the Cretaceous and Paleogene: an ocean drilling program expedition to Shatsky Rise, Northwest Pacific," Geological Society of America Today, vol. 12, no. 11, pp. 4-10, 2002.

[2] T. J. Bralower, I. Premoli Silva, and M. J. Malone, Proceedings of the Ocean Drilling Program, vol. 198, Texas A\&M University, College Station, Tex, USA, 2002.

[3] J. C. Zachos, D. Kroon, P. Blum et al., "Early Cenozoic extreme climates: the Walvis Ridge transect," in Proceedings of the Ocean Drilling Program, Leg 208, 2004, http://www-odp.tamu .edu/publications/208_IR/208TOC.HTM.

[4] M. R. Petrizzo, An Early Late Paleocene Event on Shatsky Rise, Northwest Pacific Ocean (ODP Leg 198): Evidence from Planktonic Foraminiferal Assemblages, 2005.

[5] L. J. Lourens, A. Sluijs, D. Kroon et al., "Astronomical pacing of late Palaeocene to early Eocene global warming events," Nature, vol. 435, no. 7045, pp. 1083-1087, 2005.

[6] G. Bernaola, J. I. Baceta, X. Orue-Etxebarria et al., "Evidence of an abrupt environmental disruption during the mid-Paleocene biotic event (Zumaia section, western Pyrenees)," Bulletin of the Geological Society of America, vol. 119, no. 7-8, pp. 785-795, 2007.

[7] E. Thomas and J. C. Zachos, "Was the late Paleocene thermal maximum a unique event?" GFF, vol. 122, no. 1, pp. 169-170, 2000.

[8] P. F. Burollet, Contribution à l'étude stratigraphique de la Tunisie centrale, Annales des Mines et de la Géologie, Tunis, Tunisia, 1956.

[9] J. Sprong, R. P. Speijer, and E. Steurbaut, "Biostratigraphy of the Danian/Selandian transition in the southern Tethys. Special reference to the lowest occurrence of planktic foraminifera Igorina albeari," Geologica Acta, vol. 7, no. 1-2, pp. 63-77, 2009.

[10] M. S. Mtimet, N. Karoui-Yaakoub, M. F. Zagrarni, and M. H. Negra, "Biostratigraphie des foraminifères planctoniques et caractéristiques de la limite Danien/Sélandien au Nord-Ouest de la Tunisie," Revue de Paléobiologie, vol. 32, no. 1, pp. 267-280, 2013.

[11] B. S. Wade, P. N. Pearson, W. A. Berggren, and H. Pälike, "Review and revision of Cenozoic tropical planktonic foraminiferal biostratigraphy and calibration to the geomagnetic polarity and astronomical time scale," Earth-Science Reviews, vol. 104, no. 1-3, pp. 111-142, 2011.

[12] L. R. Kump, T. J. Bralower, and A. Ridgwell, "Ocean acidification in deep time," Oceanography, vol. 22, no. 4, pp. 94-107, 2009.

[13] B. Schmitz, V. Pujalte, E. Molina et al., "The global stratotype sections and points for the bases of the Selandian (Middle Paleocene) and thanetian (Upper Paleocene) stages at Zumaia, Spain," Episodes, vol. 34, no. 4, pp. 220-243, 2011. 

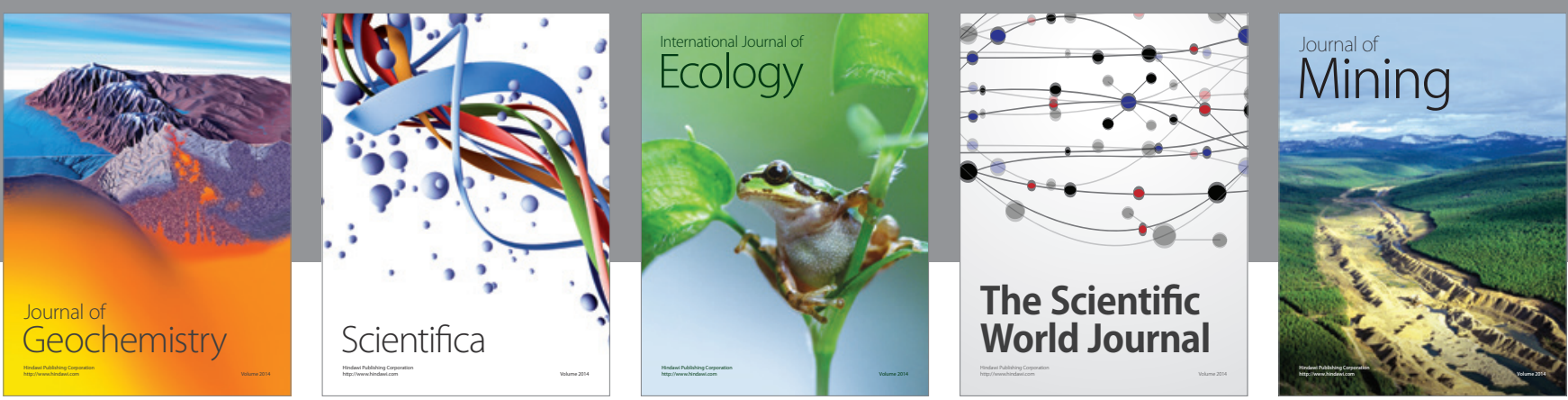

The Scientific World Journal
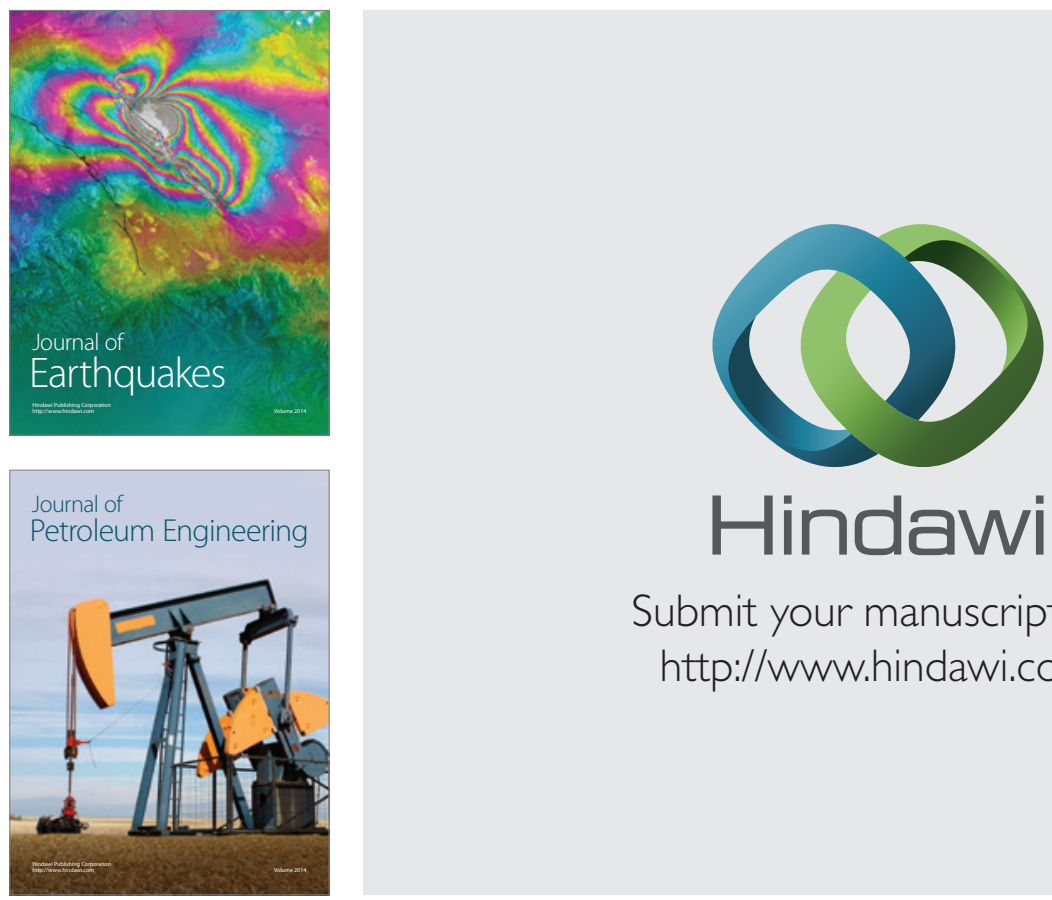

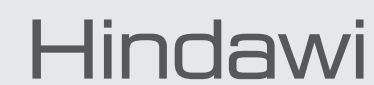

Submit your manuscripts at

http://www.hindawi.com
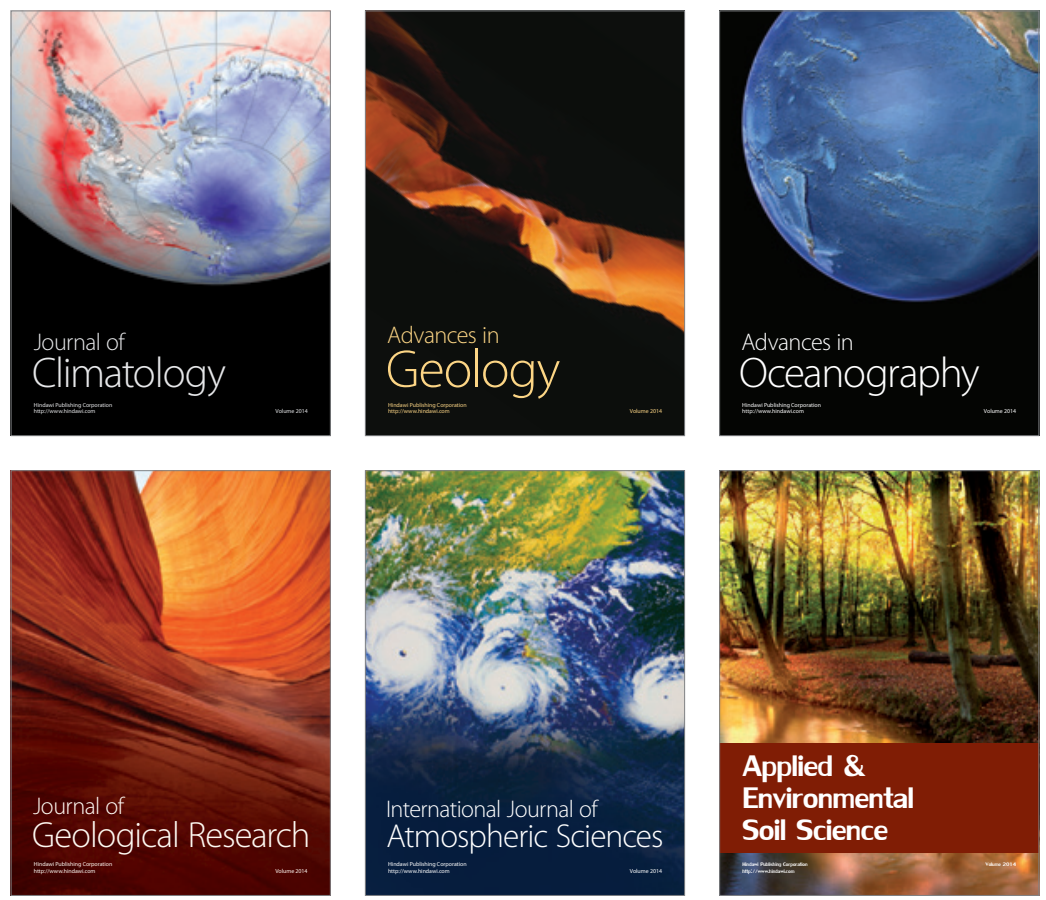
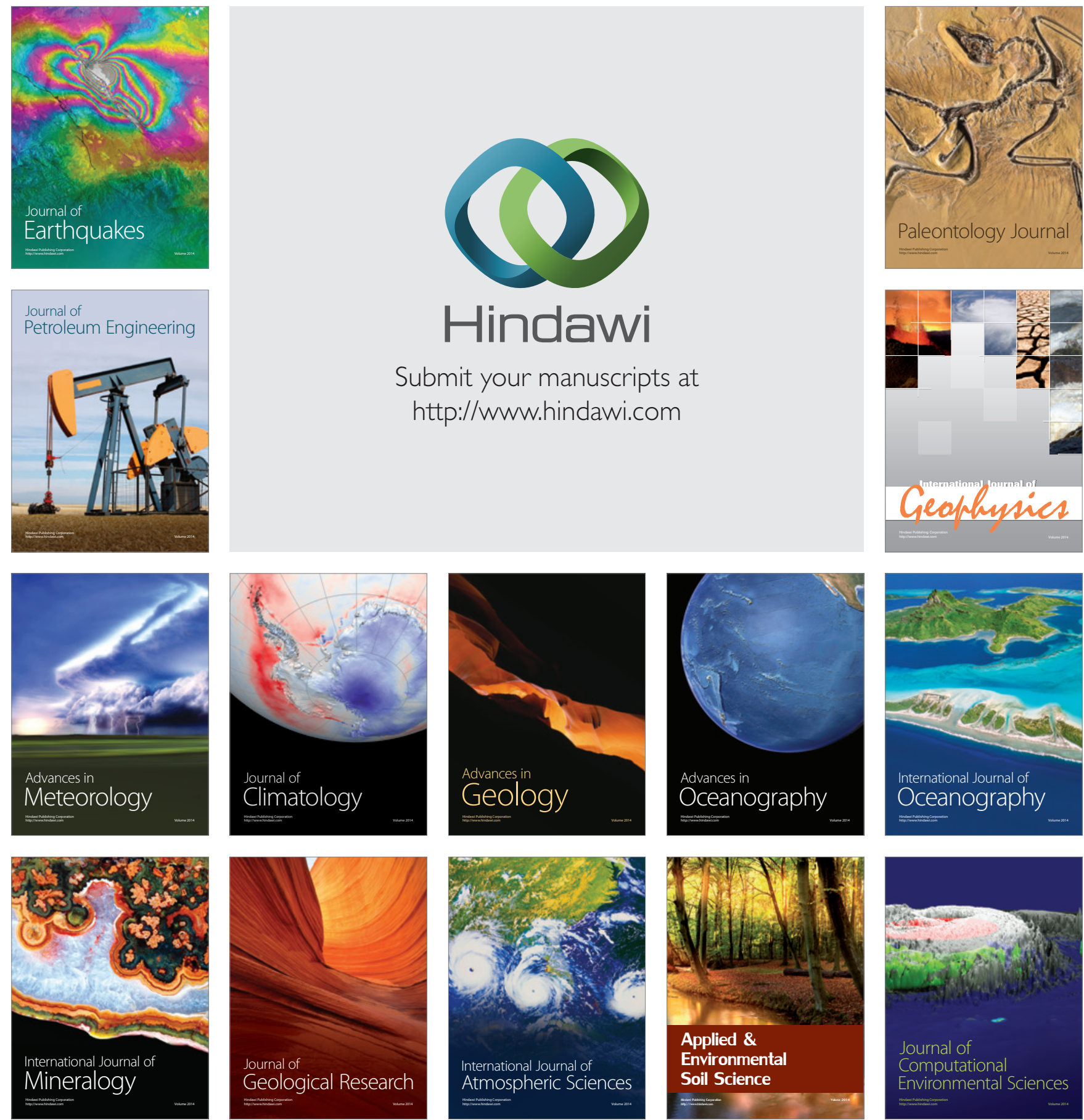